\title{
Pola Pneumonia Nosokomial di Unit Perawatan Intensif Rumah Sakit Umum Pusat Dr. Hasan Sadikin Bandung Periode Januari-Desember 2017
}

\author{
Ronald Tikuali Salukanan, Ardi Zulfariansyah, Ruli Herman Sitanggang \\ Departemen Anestesiologi dan Terapi Intensif \\ Fakultas Kedokteran Universitas Padjadjaran/RSUP Dr. Hasan Sadikin Bandung
}

\begin{abstract}
Abstrak
Pneumonia merupakan salah satu jenis infeksi nosokomial dengan jumlah kasus tertinggi dibanding dengan infeksi nosokomial lain di unit perawatan intensif (ICU) disertai jumlah morbiditas dan mortalitas yang tinggi. Pola pneumonia nosokomial merupakan suatu karakteristik pneumonia nosokomial yang digunakan untuk mengidentifikasi masalah dan dapat menjadi indikator untuk perbaikan terapi. Penelitian bertujuan menggambarkan pola pneumonia nosokomial di unit perawatan intensif RSUP Dr. Hasan Sadikin Bandung periode Januari-Desember 2017. Metode penelitian menggunakan deskriptif observasional yang dilakukan secara retrospektif terhadap 70 objek penelitian yang diambil dari rekam medis dan dilakukan dalam waktu 3 bulan, yaitu Oktober-Desember 2017. Hasil penelitian jumlah kematian akibat pneumonia nosokomial masih tinggi, yaitu $60 \%$ terutama pada pasien laki-laki usia $\geq 65$ tahun. Komorbid terbanyak pada pneumonia nosokomial, yaitu hipertensi (31,4\%) diikuti penyakit neuromuskular (15,7\%). Mikrob terbanyak penyebab HAP adalah $A$. baumannii $(38,1 \%)$, P. aeroginosa $(30,4 \%)$, dan K. pneumoniae $(15,2 \%)$, sedangkan mikrob penyebab terbanyak ventilator associated pneumonia (VAP) adalah A. baumannii (32\%), P. aeroginosa (30,5\%), dan K. pneumoniae (22\%). Mikrob A. baumannii juga menjadi penyebab mortalitas tertinggi dengan persentase $45,4 \%$ dan terapi empirik yang sering digunakan adalah kombinasi meropenem-levofloxacin (40\%), terapi tunggal meropenem (34,3\%), dan kombinasi ceftazidime-levofloxacin (20\%). Simpulan, pola pneumonia nosokomial di ICU RSUP Dr. Hasan Sadikin Bandung periode Januari-Desember 2017 masih diperlukan perbaikan program penanganan terhadap infeksi ini untuk mencapai pelayanan yang baik.
\end{abstract}

Kata kunci: Mikrob, mortalitas, pneumonia nosokomial, unit perawatan intensif

\section{Nosocomial Pneumonia Pattern in Intensive Care Unit (ICU) of Dr. Hasan Sadikin General Hospital Bandung from January to December 2017}

\begin{abstract}
Pneumonia is the most common nosocomial infection in intensive care unit with high morbidity and mortality rates. Pattern of nosocomial pneumonia is an infection characteristic that helps the identification of a phenomenon or problem and serves as an indicator or model for predicting future behaviors. These patterns can be used for making a standardized therapy management for the disease. The aim of this study was to describe nosocomial pneumonia pattern in Intensive Care Unit (ICU) in Dr. Hasan Sadikin Bandung from January to December 2017. A retrospective observational descriptive method on 70 samples from medical records with an observation period of three months starting from October to December 2017. It was shown that the mortality rate of nosocomial pneumonia was $60 \%$ with male patients aged $\geq 65$ years old as the most affected group. The most common comorbid was hypertension (31.4\%) followed by neuromuscular diseases (15.7\%). The most common HAP-causing microbes were A. baumannii (38.1\%), P. aeroginosa (30.4\%), and K. pneumoniae (15.2\%) and the most common microbes for VAP were A. baumannii (32\%), P. aeroginosa (30.5\%), and K. pneumoniae (22\%). Acinetobacter baumannii caused most deaths (45.4\%). The most common empirical therapy was meropenem-levofloxacin combination (40\%), meropenem (34.3\%), and ceftazidime-levoflocacin combination (20\%). In conclusion, pattern of nosocomial pneumonia in ICU of Dr. Hasan Sadikin General Hospital Bandung reflects a situation that therapy management for this infection needs to be improved for a proper service.
\end{abstract}

Key words: Intensive care unit, microbes, mortality, nosocomial pneumonia

Korespondensi: Ronald Tikuali Salukanan, dr., SpAn, Departemen Anestesiologi dan Terapi Intensif Fakultas Kedokteran Universitas Padjadjaran/RSUP Dr. Hasan Sadikin Bandung, Jl. Pasteur No. 38 Bandung 40161, Email ronaldtikuali@ gmail.com 


\section{Pendahuluan}

Infeksi nosokomial atau hospital acquired infection merupakan salah satu masalah kesehatan utama yang meningkatkan angka morbiditas dan mortalitas pada pasien yang dirawat di rumah sakit. Menurut data World Health Organization (WHO) berdasar atas survei prevalensi yang dilakukan di 55 rumah sakit yang mewakili 4 wilayah (Eropa, Asia Tenggara, Mediterania Timur, dan Pasifik Barat) menunjukkan bahwa rata-rata 8,7\% pasien yang dirawat di rumah sakit menderita infeksi nosokomial. Angka kejadian infeksi nosokomial di unit perawatan intensif atau intensive care unit (ICU) berkisar 2-5 kali lebih tinggi dibanding dengan pasien yang menjalani perawatan di luar ICU. Menurut penelitan rumah sakit di India Timur, infeksi nosokomial terbanyak di ICU adalah pneumonia nosokomial, yaitu sekitar $62,07 \%$, diikuti oleh infeksi traktus urinarius $(27,59 \%)$ dan infeksi akibat pemasangan central venous catheter $(10,34 \%){ }^{1,2}$

Pada penelitian di Kanada tentang Hospital acquired pneumonia (HAP), angka mortalitas bervariasi mulai dari $7 \%$ di ruang perawatan biasa hingga $62 \%$ pada pasien dengan komorbid immunosupresan. Angka mortalitas VAP bervariasi antara 24\% hingga $50 \%$ dan dapat mencapai $76 \%$ pada infeksi paru yang disebabkan oleh mikrob high risk. Penelitian tersebut menunjukkan bahwa pneumonia nosokomial memiliki morbiditas dan mortalitas yang tinggi. ${ }^{3}$

Untuk mengurangi mortalitas dan morbiditas yang tinggi akibat pneumonia nosokomial di unit perawatan intensif program penanganan yang dibentuk berdasar atas pola penyakit di tempat tersebut sangat direkomendasikan. Pola pneumonia nosokomial merupakan karakteristik pneumonia nosokomial berupa data demografi pasien, etiologi, komorbid, uji mikrobiologi dan resistensi, diagnosis, manajemen terapi, serta jumlah kematian yang dapat digunakan untuk mengidentifikasi fenomena atau masalah yang terjadi akibat infeksi ini, serta dapat menjadi indikator untuk perbaikan penanganan infeksi pneumonia nosokomial. ${ }^{4}$

Mengacu pada identifikasi masalah, tujuan penelitian ini adalah mendeskripsikan pola pneumonia nosokomial di unit perawatan intensif RSUP Dr. Hasan Sadikin Bandung periode Januari-Desember 2017.

\section{Subjek dan Metode}

Penelitian ini merupakan penelitian deskriptif dengan pendekatan retrospektif mengenai pola pneumonia nosokomial di unit perawatan intensif RSUP Dr. Hasan Sadikin Bandung periode Januari-Desember 2017. Penelitian dilakukan setelah mendapatkan persetujuan dari Komite Etik Penelitian Kesehatan RSHS/ Fakultas Kedokteran Universitas Padjadjaran. Penelitian dilakukan selama 3 bulan, yaitu bulan Oktober-Desember 2017 menggunakan data berupa rekam medis pasien pneumonia nosokomial di ICU RSUP Dr. Hasan Sadikin Bandung.

Pemilihan subjek pada penelitian ini dilakukan berdasar kriteria inklusi, yaitu semua rekam medis pasien dengan diagnosis hospital-acquired pneumonia (baik itu yang terjadi di ruang perawatan biasa atau di rumah sakit luar) dan ventilator-associated pneumonia yang terjadi di ICU Rumah Sakit Umum Pusat Dr. Hasan Sadikin (RSHS) Bandung periode Januari-Desember 2017 dengan kriteria pengeluaran, yaitu rekam medis yang tidak lengkap.

Teknik pengambilan sampel adalah total sampling dan didapatkan jumlah sampel 76 rekam medik pasien dengan diagnosis hospital acquired pneumonia (HAP) dan ventilator associated pneumonia (VAP). Terdapat enam subjek penelitian yang dikeluarkan dari penelitian ini dikarenakan data rekam medis yang tidak lengkap berupa ketiadaan flowchart dan hasil laboratorium yang digunakan untuk menegakkan diagnosis HAP dan VAP. Data yang diteliti meliputi usia, jenis kelamin, diagnosis, antimikrob, kultur mikrobiologi, dan jumlah mortalitas. Data yang sudah terkumpul diolah secara komputerisasi untuk mengubah data menjadi informasi melalui proses editing, coding, data entry, dan cleaning. Deskripsi pola 
Tabel 1 Karakteristik Umum Pasien

\begin{tabular}{lcc}
\hline \multicolumn{1}{c}{ Data Demografi } & $\begin{array}{c}\text { Frekuensi } \\
\text { (n=70) }\end{array}$ & \% \\
\hline Kategori usia (tahun) & 6 & 8 \\
$17-25$ & 16 & 23 \\
$26-35$ & 6 & 8 \\
$36-45$ & 10 & 15 \\
$46-55$ & 16 & 23 \\
56-64 & 16 & 23 \\
$\quad$ 65 & & \\
Jenis kelamin & 42 & 60 \\
$\quad \begin{array}{l}\text { Laki-laki } \\
\text { Perempuan }\end{array}$ & 28 & 40 \\
$\begin{array}{l}\text { Diagnosis pneumonia } \\
\text { nosokomial }\end{array}$ & & \\
$\begin{array}{l}\text { Hospital acquired } \\
\text { pneumonia (HAP) }\end{array}$ & 41 & 59 \\
$\begin{array}{l}\text { Ventilator associated } \\
\text { pneumonia (VAP) }\end{array}$ & 29 & 41 \\
Keadaan pasien keluar \\
dari ICU
\end{tabular}

Keterangan: untuk data kategorik disajikan dengan jumlah/frekuensi dan persentase

pneumonia ditampilkan dalam bentuk tabel. Data kategorik dideskripsikan dengan jumlah (n) dan persentase (\%).

\section{Hasil}

Karakteristik umum pasien yang diteliti meliputi data demografi berupa usia, jenis kelamin, kejadian pneumonia nosokomial, dan angka mortalitas. Pasien yang diteliti memiliki usia 17-82 tahun dengan kelompok usia terbanyak adalah kelompok usia dewasa muda (26-35 tahun), lansia akhir (56-64 tahun), dan manula ( $\geq 65$ tahun) masingmasing 22,8\%. Jenis kelamin laki-laki lebih banyak (60\%) dibanding dengan perempuan (40\%). Kejadian hospital acquired pneumonia (HAP) lebih banyak (59\%) dibanding dengan ventilator associated pneumonia (41\%). Angka mortalitas akibat pneumonia nosokomial di
Tabel 2 Karakteristik Umum Pasien terhadap Mortalitas

\begin{tabular}{lcc}
\hline \multirow{2}{*}{ Variabel } & \multicolumn{2}{c}{ Jumlah Mortalitas } \\
\cline { 2 - 3 } & $\begin{array}{c}\text { Frekuensi } \\
\text { (n=42) }\end{array}$ & \% \\
\hline Kategori usia (tahun) & 3 & 7 \\
$17-25$ & 7 & 17 \\
$26-35$ & 3 & 7 \\
$36-45$ & 6 & 12 \\
$46-55$ & 10 & 25 \\
$56-64$ & 13 & 32 \\
$\geq 65$ & & \\
Jenis kelamin & 25 & 59 \\
Laki-laki & 17 & 40 \\
Perempuan & 27 & 64 \\
$\begin{array}{l}\text { Hospital acquired } \\
\text { pneumonia (HAP) }\end{array}$ & 15 & 36 \\
Ventilator associated & & \\
pneumonia (VAP) & & \\
\hline
\end{tabular}

Keterangan: untuk data kategorik disajikan dengan jumlah/frekuensi dan persentase

ICU adalah 60\% (Tabel 1).

Penelitian ini juga menggambarkan karakteristik umum pasien terhadap jumlah kematian selama perawatan di ICU. Jumlah kematian terbanyak pada golongan usia $\geq 65$ tahun (26\%), diikuti oleh usia 56-64 tahun (24\%) sementara jumlah kematian terendah pada usia 36-45 tahun dan usia 17-25 tahun (7\%). Jenis kelamin laki-laki memiliki jumlah kematian lebih tinggi (60\%) dibanding dengan perempuan $(40 \%)$. Pasien dengan hospital acquired pneumonia (HAP) mempunyai jumlah kematian yang lebih tinggi, yaitu $64 \%$ dibanding dengan ventilator associated pneumonia (VAP) sebesar $36 \%$ (Tabel 2).

Berdasar atas data yang diperoleh, angka insidensi VAP di ICU RSUP Dr. Hasan Sadikin Bandung adalah 8,5 kasus per 1.000 hari ventilator. Angka mortalitas akibat pneumonia nosokomial di ICU RSUP Dr. Hasan Sadikin Bandung masih tinggi. Hal ini dapat dilihat dari angka mortalitas hospital acquired pneumonia, (HAP), yaitu 66\% dan ventilator-associated pneumonia (VAP), yaitu 52\% (Tabel 3). 
Tabel 3 Karakteristik Pneumonia Nosokomial terhadap Insidensi dan Mortalitas

\begin{tabular}{lcccc}
\hline \multirow{2}{*}{ Variabel } & Jumlah Kejadian & $\begin{array}{c}\text { Angka } \\
\text { Insidensi }\end{array}$ & $\begin{array}{c}\text { Frekuensi } \\
\text { Mortalitas }\end{array}$ & $\begin{array}{c}\text { Angka } \\
\text { Mortalitas }\end{array}$ \\
\cline { 2 - 6 } & $\mathbf{n}$ & $\begin{array}{c}\mathbf{n} / \mathbf{1 . 0 0 0} \\
\text { hari }\end{array}$ & $\mathbf{n}$ & $\mathbf{\%}$ \\
\hline Hospital acquired pneumonia (HAP) & 41 & - & 25 & 66 \\
Ventilator associated pneumonia (VAP) & 29 & $8,5^{*}$ & 17 & 52 \\
\hline
\end{tabular}

Keterangan: untuk data kategorik disajikan dengan jumlah/frekuensi dan persentase, *jumlah kasus VAP perjumlah pemakaian vantilator dikali rata-rata waktu pemakaian ventilator dikali 1.000

Beberapa komorbid yang sering ditemui pada pneumonia nosokomial di ICU RSUP Dr. Hasan Sadikin Bandung adalah hipertensi dan perdarahan intraserebral 31,4\%, diikuti oleh penyakit neuromuskular (Guillain Barre syndrome, miastenia gravis, duschene muscular distrophy), acute kidney injury 16\%, serta diabetes melitus 11,4\%.

Data jenis mikrob penyebab pneumonia nosokomial diambil berdasar atas jumlah pemeriksaan kultur mikrobiologi sputum yang dilakukan selama pasien di ICU. Jenis

Tabel 4 Gambaran Mikrobiologi Sputum Penyebab Pneumonia Nosokomial

\begin{tabular}{lcccc}
\hline & \multicolumn{4}{c}{ Jumlah Pemeriksaan (n=164) } \\
\cline { 2 - 5 } \multicolumn{1}{c}{ Jenis Mikrob } & n & HAP & VAP & \% \\
\hline Acinetobacter baumannii & 40 & 38 & 19 & 32 \\
Pseudomonas aeruginosa & 32 & 30 & 18 & 31 \\
Klebsiella pneumoniae & 16 & 15 & 13 & 22 \\
Acinetobacter iwoffii & 1 & 1 & 1 & 1 \\
Buruholderra cepacea & 1 & 1 & 0 & 0 \\
Enterobacter asburiae & 1 & 1 & 0 & 0 \\
Enterobacter cloacae & 0 & 0 & 1 & 1 \\
Enterobacter cloacae complex & 2 & 2 & 0 & 0 \\
Escherichia coli & 2 & 2 & 3 & 3 \\
Klebsiella oxytoca & 1 & 1 & 0 & 0 \\
Kocuria kristinae & 1 & 1 & 0 & 0 \\
Micrococcus & 1 & 1 & 0 & 0 \\
Raoultella planticola & 1 & 1 & 1 & 0 \\
Staphylococcus aureus & 0 & 0 & 0 & 1 \\
Staphylococcus epidermidis & 1 & 1 & 1 & 0 \\
Staphylococcus hominis & 1 & 1 & 2 & 1 \\
Stenotrophomonas maltophilia & 1 & 1 & 0 & 2 \\
Streptococcus cutis & 1 & 1 & 0 & 0 \\
Streptococcus mitis & 1 & 1 & 0 \\
Streptococcus viridans & 1 & 1 & 0 \\
\hline Keternyyyy & & 1 & 0 & 0 \\
\hline
\end{tabular}

Keterangan: untuk data kategorik disajikan dengan jumlah/frekuensi dan persentase 
Tabel 5 Gambaran Sensitivitas Antimikrob Sebagai Terapi Pneumonia Nosokomial

\begin{tabular}{lccccccccccc}
\hline \multirow{2}{*}{ Jenis Mikrob } & \multicolumn{2}{c}{ Meropenem } & \multicolumn{2}{c}{ Amikasin } & \multicolumn{2}{c}{ Tigecyclin } & \multicolumn{2}{c}{ Cefepime } & \multicolumn{2}{c}{ Ceftazidime } \\
\cline { 2 - 11 } & Frek. & \% & Frek. & \% & Frek. & \% & Frek. & \% & Frek. & \% \\
\hline A. baumannii & 9 & 19,2 & 56 & 57,7 & 53 & 67,1 & 0 & 0 & 0 & 0,0 \\
P. aeruginosa & 15 & 31,9 & 22 & 22,7 & 1 & 1,3 & 30 & $97 \%$ & 18 & 94,7 \\
K. pneumoniae & 23 & 48,9 & 19 & 19,6 & 25 & 31,6 & 1 & $3 \%$ & 1 & 5,3 \\
\hline
\end{tabular}

Keterangan: untuk data kategorik disajikan dengan jumlah/frekuensi dan persentase

mikrob penyebab pneumonia nosokomial di unit perawatan intensif RSUP Dr. Hasan Sadikin Bandung tahun 2017 yang terbanyak adalah Acinetobacter baumannii (38\%) diikuti Pseudomonas aeruginosa (30\%) dan Klebsiella pneumoniae (15\%; Tabel 4).

Dari penelitian ini didapatkan terapi empirik pneumonia nosokomial di ICU
RSUP Dr. Hasan Sadikin Bandung sebagian besar berupa terapi kombinasi. Kombinasi meropenem-levofloxacin merupakan terapi empirik yang paling banyak digunakan (40\%), diikuti, terapi tunggal meropenem (34\%) serta terapi kombinasi ceftazidime-levofloxacin $20 \%$.

Sensitivitas antimikrob amikasin terhadap

Tabel 6 Gambaran Jenis Mikroba dengan Jumlah Kematian

\begin{tabular}{lcccc}
\hline \multirow{2}{*}{ Jenis Mikrob } & \multicolumn{2}{c}{ Hidup } & \multicolumn{2}{c}{ Meninggal } \\
\cline { 2 - 5 } & Jumlah & \% & Jumlah & $\mathbf{\%}$ \\
\hline Acinetobacter baumannii & 19 & 25 & 40 & 45 \\
Pseudomonas aeruginosa & 26 & 34 & 24 & 27 \\
Klebsiella pneumoniae & 14 & 18 & 14 & 16 \\
Acinetobacter iwoffii & 1 & 1 & 0 & 0 \\
Buruholderra cepacea & 0 & 0 & 1 & 1 \\
Enterobacter asburiae & 0 & 0 & 1 & 1 \\
Enterobacter cloacae & 1 & 1 & 0 & 0 \\
Enterobacter cloacae complex & 2 & 3 & 0 & 0 \\
Escherichia coli & 2 & 3 & 3 & 4 \\
Klebsiella oxytoca & 2 & 3 & 0 & 0 \\
Kocuria kristinae & 1 & 1 & 0 & 0 \\
Micrococcus & 0 & 0 & 1 & 1 \\
Raoultella planticola & 1 & 1 & 0 & 0 \\
Staphylococcus aureus & 1 & 1 & 0 & 0 \\
Staphylococcus epidermidis & 0 & 0 & 1 & 1 \\
Staphylococcus hominis & 1 & 1 & 1 & 1 \\
Stenotrophomonas maltophilia & 2 & 3 & 1 & 1 \\
Streptococcus cutis & 1 & 1 & 0 & 0 \\
Streptococcus mitis & 1 & 1 & 0 & 0 \\
Streptococcus viridans & 0 & 0 & 1 & 1 \\
\hline
\end{tabular}

Keterangan: pada setiap pasien ditemukan lebih dari satu jenis mikroba sehingga jumlah nilai persentase akan lebih dari $100 \%$ 
Acinetobacter baumanii lebih tinggi (58\%) dibanding dengan Pseudomonas aeruginosa (23\%) dan Klebsiella pneumoniae (20\%). Sebaliknya, antimikrob meropenem lebih sensitif terhadap Klebsiella pneumoniae (49\%) dibanding dengan Pseudomonas aeruginosa (32\%) dan Acinetobacter baumannii (19\%). Sama hal dengan amikasin, antimikrob tigecyclin lebih sensitif terhadap Acinetobacter baumannii (67\%) dibanding dengan Klebsiella pneumoniae (32\%) dan Pseudomonas aeruginosa 1\%. Antimikrob golongan sefalosporin tidak mempunyai sensitifitas terhadap mikrob Acinetobacter baumannii dan sensitivitas yang rendah pada Klebsiella pneumoniae. Namun, untuk mikrob Pseudomonas aeruginosa antimikrob golongan sefalosporin seperti cefepime dan ceftazidime masih mempunyai sensitivitas yang tinggi (Tabel 5).

Data yang ditampilkan berikut adalah gambaran jenis mikrob dengan jumlah kematian yang ditemukan dalam pemeriksaan kultur mikrobiologi sputum. Jumlah kematian banyak didapatkan pada pasien pneumonia nosokomial dengan jenis mikrob Acinetobacter baumannii sebesar 45\%, diikuti mikrob Pseudomonas aeruginosa sebesar $27 \%$ dan mikrob Klebsiella pneumoniae sebesar 16\% (Tabel 6).

\section{Pembahasan}

Hasil penelitian ini didapatkan dari 70 subjek penelitian dengan pneumonia nosokomial yang menjalani perawatan di Unit Perawatan Intensif RSUP Dr. Hasan Sadikin Bandung periode Januari-Desember 2017. Pasien yang banyak dirawat berdasar atas golongan usia adalah dewasa muda (26-35 tahun), dewasa akhir (56-64 tahun), dan manula ( $\geq 65$ tahun) dengan persentase masing-masing $23 \%$. Jenis kelamin laki-laki lebih banyak (60\%) dibanding dengan perempuan (40\%). Penelitian tahun 2015 terhadap 166 pasien di Inggris didapatkan bahwa usia terbanyak penderita pneumonia adalah usia $\geq 65$ tahun. $^{5}$ Begitu pula penelitian tahun 2010 terhadap 351 pasien ICU yang dirawat dengan diagnosis pneumonia dinyatakan bahwa peningkatan usia berhubungan dengan mortalitas jangka pendek maupun jangka panjang. ${ }^{5}$

Beberapa faktor yang memengaruhi meningkatkan mortalitas pada usia tua adalah penyakit penyerta, penurunan sistem imun, dan sering terpapar antimikrob seiring usia yang bertambah. Penelitian ini menemukan usia tua $\geq 65$ tahun memiliki risiko mortalitas lebih tinggi dibanding dengan kelompok usia lain. Menarik untuk dilihat bahwa usia dewasa muda (26-35 tahun) juga memiliki persentase yang hampir sama dengan usia yang lebih tua, dari data yang diperoleh menunjukkan bahwa pasien usia ini terinfeksi pneumonia nosokomial karena membutuhkan perawatan yang panjang akibat penyakit neuromuskular, pascabedah, dan keganasan. Laki-laki lebih sering terinfeksi pneumonia dibanding dengan perempuan karena hormon estrogen pada perempuan dapat mengaktivasi nitric oxide synthase-3 (NOS3) yang meningkatkan kerja makrofag dalam membunuh mikrob penyebab infeksi. ${ }^{6,7}$

Penelitian ini menunjukkan bahwa jumlah kematian akibat pneumonia nosokomial masih tinggi, yaitu $60 \%$. Mortalitas pada HAP lebih tinggi (66\%) dibanding dengan VAP (52\%) dengan angka insidensi VAP pada penelitian ini, yaitu 8,5 kasus per 1.000 hari pemakaian ventilator. Angka insidensi ini cukup tinggi, namun masih dalam batas toleransi di negara berkembang. Beberapa penelitian di negara berkembang menyatakan angka insidensi VAP berkisar $1,2-8,5$ per 1.000 hari pemakaian ventilator. Sementara di negara maju seperti Amerika angka insidensi VAP berkisar 0,24,4 per 1.000 hari pemakaian ventilator. Pasien HAP yang dirawat intensif biasanya telah menjalani perawatan di ruang biasa sebelumnya sehingga resistensi kuman sudah tinggi dan ketika masuk perawatan intensif karena gejala klinis yang memburuk tingkat mortalitas semakin tinggi. Hal tersebut yang menyebabkan mortalitas HAP lebih tinggi dibanding dengan VAP. ${ }^{8}$

Dari penelitian ini didapatkan komorbid paling banyak adalah hipertensi, penyakit neuromuskular, acute kidney injury, diabetes 
melitus, cedera kepala, dan penyakit paru obstruktif kronik (PPOK). Penelitian yang dilakukan di Jepang pada tahun 2012 terhadap 118 pasien dengan hipertensi emergency dinyatakan bahwa infeksi pneumonia lebih cepat timbul pada pasien tersebut. Hal ini berhubungan dengan outcome pasien dengan hipertensiemergencysepertistrokdenganklinis penurunan kesadaran dan disfagia. Penurunan kesadaran memanjangkan perawatan dengan ventilator sementara disfagia menimbulkan risiko mikroaspirasi. Strok iskemik akibat hipertensi dapat menimbulkan stroke-induced immunodeficiency dengan ciri hilangnya fungsi limfosit, produksi sitokin berkurang, jumlah monosit berkurang, dan defisiensi interferon-' $\Upsilon$. Hal tersebut juga menjadi faktor risiko infeksi pneumonia. ${ }^{9}$

Hasil penelitian yang dilakukan di Amerika Serikat pada tahun 2017 dinyatakan bahwa diabetes melitus menjadi salah satu komorbid yang meningkatkan mortalitas pada infeksi pneumonia. Penelitian tersebut dilakukan terhadap 7.303 pasien di 40 rumah sakit dalam 5 tahun. Penelitian tersebut menyatakan bahwa pasien pneumonia dengan diabetes melitus mempunyai mortalitas yang tinggi karena infeksi pneumonia mencetuskan kondisi hiperglikemia, begitupun sebaliknya hiperglikemia menyebabkan kerusakan organ sehingga semakin menurunkan kondisi pada pasien dengan infeksi pneumonia. Kondisi hiperglikemia menyebabkan kadar glukosa yang berlebihan dalam sel yang kemudian meningkatkan stress oxidative sehingga terjadi kerusakan mitokondria yang berujung pada kematian sel. ${ }^{10}$

Insidensi penyakit neuromuskular seperti Guillain Barre syndrome dan miastenia gravis mulai meningkat di RSUP Dr. Hasan Sadikin Bandung. Penyakit neuromuskular memengaruhi fungsi otot pernapasan sehingga fungsi respirasi terganggu dan berujung ke gagal napas. Keadaan tersebut memaksa perawatan harus dengan tirah baring dan menggunakan bantuan ventilator sehingga menjadi faktor pemicu timbulnya pneumonia. Kemampuan untuk batuk dan menelan yang terganggu pada penyakit neuromuskular menyebabkan kemungkinan aspirasi yang menyebabkan pneumonia lebih tinggi. ${ }^{11}$

Penelitian pada tahun 2014 di China terhadap 15.562 rekam medis pasien yang dirawat selama tahun 1996-2010 didapatkan hasil bahwa pasien dengan penyakit ginjal kronik lebih mudah terinfeksi pneumonia. Hal tersebut disebabkan oleh keadaan uremia menyebabkan gangguan fungsi monosit, gangguan fungsi neutrofil, limfosit $\mathrm{T}$, limfosit $\mathrm{B}$, dan peningkatan mediator inflamasi seperti sitokin. ${ }^{12}$

Sama dengan komorbid lain, penyakit paru obstruktif kronik (PPOK) juga memperberat infeksi pneumonia. Pasien dengan PPOK mengalami kerusakan pada epitel dan silia di saluran pernapasan sehingga meningkatkan produksi sel goblet. Sel goblet adalah sel yang memproduksi sputum tempat berkembang mikrob. Hal ini sesuai dengan penelitian tahun 2016 terhadap 179.579 data rekam medis tahun 2006-2012 di Denmark. Penelitian tersebut menyatakan bahwa infeksi pneumonia sering terjadi pada pasien PPOK eksaserbasi akut dengan mortalitas yang tinggi. Pneumonia yang terjadi pada penderita PPOK akan membuat infeksi semakin bertambah akibat penebalan blood-gas barrier, gangguan fungsi paru bertambah, hipoksemia, inflamasi sistemik, sepsis, hingga gagal organ. ${ }^{13}$

Penelitian pada tahun 2013 terhadap 290 pasien di Taiwan dengan cedera kepala menyimpulkan bahwa ada 3 faktor yang meningkatkan risiko pasien dengan cedera kepala berat terinfeksi pneumonia, yaitu usia, pemasangan nasogastric tube (NGT), dan hemiplegia atau hemiparesis. Pasien cedera kepala berat (GCS $\leq 8$ ) dengan defisit neurologis seperti susah menelan, kelumpuhan ekstremitas, dan gagal napas lebih cepat terinfeksi pneumonia. Risiko mikroaspirasi mudah terjadi pada penderita dengan kesulitan menelan, serta tirah baring yang lama dengan posisi yang tidak benar. Pasien cedera kepala berat dengan bantuan ventilasi mekanik mempunyai risiko tinggi terjadi kolonisasi bakteri pada jalan napas, mikroaspirasi, dan akhirnya VAP akibat penggunaan ventilator yang lama. ${ }^{14}$ 
Dari hasil penelitian ini digambarkan bahwa Acinetobacter baumannii merupakan penyebab terbanyak pneumonia nosokomial di ICU RSUP Dr. Hasan Sadikin Bandung periode Januari-Desember 2017 diikuti Pseudomonas aeruginosa dan Klebsiella pneumoniae. Ketiga jenis mikrob ini masuk dalam mikrob dengan potensi multi-drug resistant (MDR) yang tinggi sehingga mortalitas dan morbiditas meningkat, biaya perawatan membengkak karena antibiotik yang sensitif semakin sulit didapatkan, dan intervensi medis semakin bertambah untuk mempertahankan hidup pasien. ${ }^{15,16}$

Infectious Disease Society of America (IDSA) bahkan membuat suatu singkatan bagi mikrob yang mempunyai tingkat MDR yang tinggi, yaitu "ESKAPE" Enterococcus faecium, Staphylococcus aureus, Klebsiella pneumoniae, Acinetobacter baumannii, Pseudomonas aeruginosa and Enterobacter spp. Semua mikrob tersebut merupakan mikrob yang paling sering mengancam jiwa pada pasien penyakit kritis dan immunocompromised karena kemampuannya untuk menjadi resisten terhadap banyak antimikrob. ${ }^{15,16}$

Resistensi mikrob diperoleh melalui tiga mekanisme antara lain inaktivasi obat, mengubah tempat obat berikatan dengan reseptornya, dan juga mengubah permeabilitas sel sehingga akumulasi obat intrasel menurun. Inaktivasi obat diperoleh mikrob dengan menghasilkan enzim seperti $\beta$-lactamase, aminoglycoside-modifying enzymes, atau chloramphenicol acetyltransferase. Dari ketiga enzim tersebut $\beta$-lactamase merupakan hal yang sering diteliti saat ini. Enzim ini bertugas menghidrolisis cincin $\beta$-lactam yang ada pada antimikrob seperti penicillins, cephalosporins, monobactams, dan carbapenems. ${ }^{17}$

Ambler scheme dan sistem bush-jacobymedeiros merupakan sistem klasifikasi yang dipakai untuk enzim $\beta$-lactamase. Beberapa enzim yang masuk Ambler scheme adalah enzim penicillinase, cephalosporinase, broadspectrum $\beta$-lactamase, extended-spectrum $\beta$-lactamase (ESBL), carbamapenemase, metallo- $\beta$-lactamase (MBL), AmpC $\beta$-lactamase, enzim penicillinase cephalosporinase, oxacillin hydrolyzing enzymes (OXA), dan OXA-carbapenemase. Enzim-enzim tersebut terdapat pada Klebsiella pneumoniae, Enterobacter spp., Acinetobacter bauamnnii, dan Pseudomonas aeruginosa. ${ }^{17}$

Acinetobacter baumanii merupakan salah satu spesies Acinetobacter yang menyebar luas dan sangat mudah mengontaminasi lingkungan rumah sakit. Acinetobater baumannii merupakan mikrob gram negatif nonfermentasi berbentuk kokus dan basil. Patogen ini dapat bertahan hidup lama di telapak tangan manusia sehingga sangat mudah terjadi kontaminasi silang pada infeksi nosokomial. Mikrob ini dapat menjadi penyebab infeksi di berbagai tempat termasuk saluran pernapasan dan saluran kemih. ${ }^{17}$

Pseudomonas aeruginosa ialah mikrob gram negatif berbentuk batang, bersifat fakultatif anaerob, dan merupakan flora normal usus. Penyebaran mikrob ini jarang ditemukan di luar rumah sakit, namun sangat tinggi di rumah sakit terutama pada pasien immunocompromised. Pasien terinfeksi kebanyakan melalui hubungan dengan lingkungan luar secara langsung dan tidak langsung. Generasi Pseudomonas aeruginosa menunjukkan kekebalan terhadap antimikrob terutama generasi yang mempunyai enzim carbapenemase-resistant. Selain itu, $P$. aeruginosa juga memproduksi enzim ESBLs yang dapat menggandeng enzim lain seperti $K$. pneumoniae carbapenemases (KPC), Verona integron encoded metallo- $\beta$-lactamase (VIM), dan imipenem metallo- $\beta$-lactamase. Gabungan enzim tersebut membuat mikrob ini semakin resisten termasuk terhadap golongan fluoroquinolon. ${ }^{17}$

Klebsiella pneumoniae merupakan spesies dari famili Enterobacteriaceae. Mikrob ini berbentuk basil gram negatif tidak berkapsul. Mikrob ini banyak ditemukan di rumah sakit dan menyebar melalui kontak langsung dengan pasien yang sudah terinfeksi sebelumnya. Beberapa tahun terakhir ditemukan generasi $K$. pneumoniae yang mempunyai jenis enzim $\beta$-lactamase yang banyak sehingga dapat menghancurkan struktur antimikrob $\beta$-lactam seperti penisilin, 
sefalosporin, dan karbapenem. Golongan karbapenem merupakan antimikrob yang banyak digunakan sebagai terapi infeksi oleh mikroba gram negatif sehingga belakangan ini sudah mulai terbentuk carbapenemasemediated multidrug resistant (MDR). Sampai saat ini kondisi ini belum dapat dieradikasi, tetapi hanya dapat dikurangi. Oleh karena itu, terapi empirik yang optimal diperlukan bagi mikrob seperti ini. ${ }^{17}$

Staphylococcus aureus adalah mikrob gram positif berbentuk kokus dengan gambaran mikroskopis seperti kumpulan anggur, nonfastidious, dan merupakan flora normal dari kulit, daerah hidung, serta perineum manusia dan hewan. Penularannya cukup luas di populasi umum melalui kontak langsung dengan manusia yang terinfeksi atau melalui udara. Pada mulanya mikrob ini sensitif terhadap golongan penisilin, namun karena pemakaian antimikrob ini yang berlebihan maka pada abad 20 mikrob ini mulai resisten terhadap penisilin. Pada tahun 1960 ditemukan methicillin-resistant Staphylococcus aureus (MRSA) yang resisten terhadap golongan penisilin, namun masih sensitif terhadap antimikrob golongan glycopetide, yaitu vankomisin. Namun, pada tahun 1990 peneliti di Jepang menemukan mikrob $S$. aureus yang mempunyai vancomycin-intermediate dan vancomycin-resistant $S$. aureus (VISA dan VRSA). Saat ini mikrob tersebut menyebar di Asia, Amerika, dan Eropa. ${ }^{17}$

Enterobacter spp. merupakan mikrob gram negatif, nonfastidious, berbentuk batang, dan tidak berkapsul. Mikrob ini bersifat oportunistik terutama terhadap pasien immunocompromised, penyebarannya banyak di rumah sakit, dengan tingkat resistensi yang tinggi terhadap semua jenis antimikrob. Banyak generasi Enterobacter mempunyai enzim ESBLs dan karbapenemase termasuk VIM, OXA, metallo- $\beta$-lactamase sehingga risiko MDR sangat tinggi. Mikrob ini resisten terhadap semua antimikrob, namun beberapa masih sensitif terhadap tigecyclin dan colistin. ${ }^{17}$

Jika dilihat dari hasil penelitian, terapi empirik di ICU RSHS yang berupa kombinasi meropenem-levofloxacin masih efektif untuk pneumonia nosokomial yang disebabkan oleh Pseudomonas aeruginosa dan Klebsiella pneumoniae. Perlu dipertimbangkan pula bahwa mikrob terbanyak yang ditemukan sebagai penyebab HAP maupun VAP adalah A. baumannii yang lebih sensitif terhadap antimikrob seperti amikasin dan tigecyclin dibanding dengan meropenem. Penelitian rumah sakit di India pada tahun 2007 menemukan bahwa mikrob carbapenemresistant Acinetobacters sudah mulai bermunculan belakangan ini. Mikrob ini mempunyai enzim AmpC $\beta$-lactamase yang merupakan penyebab resistensi terhadap golongan karbapenem. ${ }^{18}$

Penelitian ini mendapatkan golongan sefalosporin yang masih sensitif adalah cefepime dan ceftazidime yang hanya sensitif terhadap $P$. aeruginosa. Cefepime adalah antimikrob golongan sefalosproin generasi keempat dan kedua antimikrob ini sensitif terhadap Pseudomonas aeruginosa, namun resisten terhadap Acinetobacter baumannii dan Klebsiella pneumoniae. ${ }^{18,19}$

Ceftriaxon dan cefazolin merupakan dua antimikrobyangresisten terhadap ketigavarian mikrob penyebab pneumonia nosokomial di ICU RSUP Dr. Hasan Sadikin Bandung. Penelitian di India pada tahun 2007 dan di Uruguay tahun 2011 menyatakan penggunaan sefalosporin generasi ketiga menyebabkan munculnya varian carbapenemase-resistant Acinetobacter. Penelitian yang dilakukan di Uruguay menyatakan penggunaan masif sefalosporin mencetuskan resistensi dari antimikrob terhadap mikrob gram negatif yang biasa disebut resistant Gram-negative bacilli (r-GNB). Penelitian tersebut dinyatakan penggunaan ceftriaxon dan juga ciprofloxacin diprediksi dapat menjadi faktor independen timbulnya VAP dengan penyebab Acinetobacter spp..$^{20}$

Keterbatasan dalam penelitian, yaitu beberapa rekam medis yang dijadikan sampel penelitian tidak terisi lengkap. Terutama rekam medis ICU yang berupa lembaran flow chart dengan diagnosis yang tidak lengkap, hasil laboratorium yang tidak tertulis. Selain itu, lembar laboratorium seperti hasil kultur 
resistensi juga ada yang belum tertera pada rekam medis.

\section{Simpulan}

Pola pneumonia nosokomial di ICU Rumah Sakit Umum Pusat Dr. Hasan Sadikin Bandung dapat terlihat dari data demografi (usia dan jenis kelamin), data klinis (insidensi, komorbid, etiologi, diagnosis, dan pemeriksaan penunjang), serta jumlah mortalitas. Dari data demografi, pneumonia nosokomial banyak terjadi pada usia lansia akhir (56-64 tahun) dan manula ( $\geq 65$ tahun) serta jenis kelamin laki-laki lebih mudah terkena pneumonia nosokomial. Kejadian mortalitas pasien dengan pneumonia nosokomial di ICU RSUP Dr. Hasan sadikin Bandung periode Januari-Desember 2017 masih tinggi dengan persentase 60\% terutama pada usia manula ( $\geq 65$ tahun) dan laki-laki. Mortalitas pada hospital-acquired pneumonia lebih tinggi dibanding dengan ventilator-associated pneumonia. Hipertensi merupakan komorbid yang terbanyak diikuti oleh penyakit neuromuskular yang jumlah kejadiannya mulai meningkat di RSHS Bandung. Angka insidensi ventilatorassociated pneumonia di ICU RSUP Dr. Hasan Sadikin Bandung 8,5\%. Mikrob penyebab pneumonia nosokomial di ICU RSUP Dr. Hasan Sadikin Bandung adalah A. baumannii, diikuti oleh $P$. aeruginosa, dan $K$. pneumoniae. A. baumannii merupakan mikrob terbanyak penyebab mortalitas. Sensitivitas antimikrob seperti amikasin, tigecyclin, meropenem, dan sefalosporin generasi keempat masih baik. Pola tersebut di atas menunjukkan program penanganan pneumonia nosokomial di ICU RSUP Dr. Hasan Sadikin Bandung yang ada saat ini perlu ditingkatkan lagi.

\section{Daftar Pustaka}

1. Ducel G, Fabry J, Nicolle L. Prevention hospital-acquired infections a practical guide. Departement of Communicable Disease World Health Organization [diunduh 13 Maret 2017]. Tersedia dari: http://www.who.int/emc.
2. Eida M, Nasser M, El-Maraghy N, Azab K. Pattern of hospital-acquired pneumonia in Intensive Care unit of Suez Canal University Hospital [diunduh 10 Maret 2017]. Tersedia dari: http://www.elsevier. com/locate/ejcdt.

3. Rotstein C, Evans G, Born A, Grossman $\mathrm{R}$, Light RB, Magder S, dkk. Clinical practice guidelines for hospital-acquired pneumonia and ventilator-associated pneumonia in adults. Can J Infect Dis Med Microbiol. 2008;19(1):19-53.

4. Kalil AC, Metersky ML, Klompas M, Muscedere J, Sweeney DA, Palmer LB, dkk. Management of adults with hospitalacquired and ventilator-associated pneumonia: clinical practice guidelines by the infectious disease society of America and the American Thoracic Society. 2016 [diunduh 10 Maret 2017]. Tersedia dari: http://cid.oxfordjournals.org.

5. Sligl WI, Eurich DT, Marrie TJ, Majumdar SR. Age still matters: prognosticating shortand long-term mortality for critically ill patients with pneumonia. Crit Care Med. 2010;38(11):2126-32.

6. Yang Z, Huang YCT, Koziel H, Crom RD, Ruetten $\mathrm{H}$, Wohlfart $\mathrm{P}$, dkk. Female resistance to pneumonia identifies lung macrophage nitric oxide synthase- 3 as a therapeutic target. eLife United States. 2014;3(1):1-17.

7. Lee $\mathrm{Ch}, \mathrm{Wu} \mathrm{CL}$. An update on the management of hospital-acquired pneumonia in the elderly. Int J Gerontol. 2008;2(4):183-90.

8. Kalanuria AA, Zai W, Mirski M. Ventilatorassociated pneumonia in the ICU. Crit Care Med. 2014;18:1-8.

9. Ishigami K, Okuro M, Koizumi Y, Satoh K, Iritani O, Yano H, dkk. Association of severe hypertension with pneumonia in elderly patients with acute ischemic stroke. Japanese Soc Hypertens. 2012:35:648-53.

10. Bandhary S, Contreras BY, Gupta R, Fernandez P, Jimenez P, Peyrani P, dkk. Clinical outcomes of community-acquired pneumonia in patients with diabetes mellitus. J Respirat Infect. 2017;1(1):23-8. 
11. Benditt JO, Boitano LJ. Pulmonary issues in patients with chronic neuromuscular disease. Am J Respir Crit Care Med. 2013;187(10):1046-55.

12. Chou CY, Wang SM, Liang CC, Chang CT, Liu JH, Wang Ik, dkk. Risk of pneumonia among patients with chronic kidney disease in outpatient and inpatient settings; a nationwide population-based study. Taiwan J Med. 2014;93(27):1-4.

13. Sogaard M, Madsen M, Lokke A, Hilberg $\mathrm{O}$, Sorensen HT, Thomsen RW. Incidence and outcomes of patients hospitalized with COPD exacerbation with and without pneumonia. Intern J COPD. 2016;11:45565.

14. Wang KW, Chen HJ, Lu K, Liliang PC, Huang CK, Tang PL, dkk. Pneumonia in patients with severe head injury: incidence, risk factors, and outcomes. J Neurosurg. 2013:118:358-63.

15. Howard A, O'Donoghue M, Feeney A, Sleator RD, Acinetobacter baumannii an emerging opportunistic pathogen. Department of Biological Sciences; Cork Institute of Technology; Bishopstown, Cork, Ireland. 2012;3(3):243-50.
16. Yang YS, Lee YT, Huang TW, Sun JR, Kuo SC, Yang $\mathrm{CH}$, dkk. Acinetobacter baumannii nosocomial pneumonia: is the outcome more favorable in non-ventilated than ventilated patients?. BMC Infect Dis. 2013;13:142.

17. Santajit $S$, Indrawattana N. Review article: mechanisms of antimicrobial resistance in ESKAPE pathogens. Bio Med Res Intern. 2016:1:1-8.

18. Shaikh S, Fatima J, Shakil S, Rizvi SMD, Kamal MA. Antibiotic resistance and extended spectrum beta-lactamases: types, epidemiology and treatment. Saudi J Biologic Sci. 2015;22:90-101.

19. Sinha M, Srinivasa H. Mechanisms of resistance to carbapenems in meropenemresistant Acinetobacter isolates from clinical samples. Indian J Med Microbiol. 2007;25:121-5.

20. Medina Presentado JC, Paciel López D, Berro Castiglioni M, Gerez J. Ceftriaxone and ciprofloxacin restriction in an intensive care unit: less incidence of Acinetobacter spp. and improved susceptibility of Pseudomonas aeruginosa. Rev Panam Salud Publica. 2011;30(6):603-9. 